\title{
Plasmid DNA isolation and characterization studies
}

\section{Plazmid DNA izolasyonu ve karakterizasyon çalışmaları}

\section{Murat Doğan}

Department of Pharmaceutical Biotechnology, Faculty of Pharmacy, Sivas Cumhuriyet University, Sivas, Turkey.

Corresponding author: Murat Doğan, PhD, Department of Pharmaceutical Biotechnology, Faculty of Pharmacy, Sivas Cumhuriyet University, Sivas,

Turkey.

E-mail: mdogan@cumhuriyet.edu.tr

Received/Accepted: August 25, 2021 /September 25, 2021

Conflict of interest: There is not a conflict of interest.

\section{SUMMARY}

Murat Doğan

Objective: The use of gene therapy for targeted therapy in various genetic diseases has become more and more popular day by day. Various carrier vectors are used in gene therapy. The plasmid we are interested in in this study is used as a gene delivery vector. In this study, it was aimed to perform the isolation and characterization studies of the peGFP-N1 plasmid. In

ORCID IDs of the authors: addition, necessary properties were investigated to make it a suitable gene carrier vector.

Method: In this study, isolation was performed using the plasmid peGFPN1 via classical method. Escherichia coli was used as expression medium in the isolation process. In order to calculate the amount of plasmid DNA in the studies, the spectral curve value of the plasmid DNA was calculated. Spectrophotometric methods were used to determine the amount and impurity of the isolated bacterial DNA.

Results: In plasmid DNA isolation studies, it was observed that the yield was quite high and the contamination from protein or RNA was very low. In fact, the ratio of absorbance values (A1/A2) is very close to 1.8 as a result of the isolation III study shows that there is no contamination.

Conclusions: The isolation and spectrophotometric study results of the peGFP-N1 plasmid showed that this plasmid is suitable and usable in terms of impurity and contamination risk. By making use of the results of this study, it will support the studies in which this plasmid can be used in an appropriate gene carrier system.

Keywords: peGFP-N1, plasmid DNA isolation, spectrophotometric analysis, gene cassette

\section{ÖZET}

Amaç: Çeşitli genetik hastalıklarda hedefe yönelik tedavi amacıyla gen tedavisinin kullanılması gün geçtikçe daha popüler bir alan haline gelmiştir. Gen tedavisinde çeşitli taşıyıcı vektörler kullanılmaktadır. Bu çalışmada ele aldığımız plazmid ise gen taşıyıcı vektör olarak kullanılmaktadır. Bu çalışmada peGFP-N1 plazmidinin izolasyonu ve karakterizasyon çalışmalarının yapılması amaçlanmıştır. Ayrıca uygun bir gen taşıyıcı vektör olabilmesi için gerekli özellikler araştırılmıştır.

Yöntem: Bu çalışmada peGFP-N1 plazmidi kullanılarak klasik yöntemle izolasyonu yapıldı. İzolasyon işleminde Escherichia coli ekspresyon ortamı olarak kullanıldı. Çalışmalarda plazmid DNA miktarının hesaplanması amacıyla plazmid DNA' nın spektral eğri değeri hesaplandı. İzole edilmiş bakteriyel DNA'nın miktarını ve safsızlığını saptamak amacıyla spektrofotometrik yöntemler kullanıldı. 
Bulgular: Plazmid DNA izolasyon çalışmalarında verimin oldukça yüksek olduğu ve protein ya da RNA kaynaklı kontaminasyonların oldukça az miktarda olduğu gözlenmiş̧tir. Hatta üçüncü izolasyon çalışması sonucunda absorbans değerleri oranının (A1/A2) 1.8 değerine çok yakın olması kontaminasyonun olmadığını göstermektedir.

Sonuç: peGFP-N1 plazmidinin izolasyonu ve spektrofotometrik çalışma sonuçları bu plazmidin safsızlık ve kontaminasyon riski anlamında uygun ve kullanılabilir olduğunu göstermiştir. Yapılan bu çalışmanın sonuçlarından faydalanılarak bu plazmidin uygun bir gen taşıyıcı sistem içerisinde kullanılabileceği çalışmalara destek olacaktır.

Anahtar sözcükler: peGFP-N1, plazmid DNA İzolasyonu, spektrofotometrik analizler, gen kaseti

\section{INTRODUCTION}

Gene therapy has become a very popular field of study in recent years in terms of its potential to provide solutions to many genetic diseases. Gene therapy encompasses a variety of techniques that regulate missing genes by complementing them, treating genes with differentiated activity by replacing them with a healthy gene, and aiming to eliminate genetic disorders ${ }^{1}$. The main purpose of gene therapy is to transfer the therapeutic gene to target cells via a vector without any biodegradation. However, for successful gene therapy to be implemented, it is necessary to establish a perfect carrier system that ensures that therapeutic genes are directed directly to the disease site and prevents the degradation of naked genes. For this purpose, plasmids with certain properties are isolated by various methods and used for gene therapy through appropriate carrier systems ${ }^{2}$. Plasmids are usually autonomous units with the necessary genetic information to maintain their independent state within the host bacteria. One of the most important sequences to be found in plasmids is the nucleotides that encode the origin of replication (OR), which has a function in replication. In fact, small or large DNA sequences with OR may feature independent replication. Although the origin of replication is usually single in plasmids, some may have 2-3 ORs in the R6K plasmid. Plasmids have cut sites and restriction maps of some restriction endonuclease enzymes ${ }^{3}$. Enzymes divide DNA segments of different lengths by making different cuts $(0,1,2$ or more) in plasmids, depending on their species ${ }^{4}$. Some enzymes (Bst II, Hpa I and Xba I) have no cut sites in the plasmid (pBR322). In contrast, Hpa II has the ability to cut at 26 sites in this plasmid. However, in vectors to be used for gene cloning, it is desirable for some enzymes to have only one cut-off site and this site to be over one of the specific markers (EcoR I, Pst I, etc.) for gene inactivation ${ }^{5}$. Some prokaryotic (bacteria) and eukaryotic organisms (yeast, fungus, plant) have their own large chromosomes (genomic DNA) as well as other genetic elements with a much smaller DNA character, double-stranded. Plasmids are double- stranded autonomous DNA molecules. The existence of plasmids with RNA (ribonucleic acid) feature has not been reported in prokaryotic and eukaryotic organisms until now ${ }^{6}$. Plasmids in bacteria are generally circular, helical, and doublestranded. Extrachromosomal materials can be found freely in the cell cytoplasm (plasmid) or they can be combined with the bacterial chromosome. Such plasmids are called episomes. Cointegration can occur between plasmid and genomic DNA or between plasmid and plasmid. Plasmids carry some special genetic information called in codes. Both the plasmids themselves and the specific information they encode are not essential or vital for the host bacteria. Without them, the bacteria continue their normal life cycle. Because plasmids are subsequently transferred to bacteria and can be separated from bacteria under special conditions. However, they confer some special characters that are not (or sometimes can be found) in the genome of the bacterium, and offer advantages: For example, resistance to antibiotics, metals, drugs, toxin formations, pilus formation, virulence factors, fermentation characteristics, nitrogen fixation, etc.) are just a few of them. Rather than naturally occurring plasmids in bacteria, artificial plasmids (pBR322, pUC8/9 and others), which are prepared by adding the desired special markers in vitro and in accordance with the purpose, are widely used as a vector in the cloning of genes in recombinant DNA technology. Large plasmids are usually found in 1-4 copies in a bacterium, whereas small plasmids have $20-50$ copies $^{7}$. Some plasmids are called sex factors and the products of the genes they carry enable the bacterium to exchange genes with another bacterium and transfer some genes, while some types of plasmids encode factors called bacteriocins and play a role in the defense mechanism. Plasmids have nucleic acid base sequences of 1-200 kilobase pairs (kbp) in size and are relatively small in size to chromosomal DNA. Also, it is possible to increase the copy number of plasmids in bacteria by using some special techniques. Since most of the small plasmids do not fuse with the chromosome or are sufficiently present in the cytoplasm, they are easy to remove from cells. For this reason, gene transfers are 
generally more beneficial than small or medium sized artificial plasmids ${ }^{8}$. The high number of copies in the cell is also considered an advantage in terms of expression. Plasmids, which can replicate independently within the host, use the special region (mesosome) on the cytoplasmic membrane in partnership with the genome. Because mutations that prevent bacterial DNA replication also block plasmid replication ${ }^{6,9}$. In contrast, small plasmids are not affected by such mutations because they do not replicate synchronously with the bacterial chromosome. In this study, peGFP-N1 plasmid containing green fluorescent protein was used as a selection marker. This plasmid is used as an expression vector in both eukaryotic and prokaryote cells. peGFP-N1 is a plasmid with a single OR and consists of 4733 base pairs ${ }^{10}$. Figure 1 shows the structure and gene cassette of the peGFP-N1 plasmid ${ }^{11}$. In the structure of this plasmid, there are ampicillin, neomycin, kanamycin antibiotic resistance genes in order to ensure its specific production in the expression medium. There are also bacterial $\mathrm{T} 7$ promoter and enhancer locus. The plasmid has a cytomegalovirus (CMV) promoter region and a multiple cloning site (MCS) in its structure to enable it to replicate in different expression systems ${ }^{12}$. In this study, peGFP-N1 plasmid was replicated in the Escherichia (E) coli expression system and plasmid DNA was isolated. In addition, it is aimed to control and quantify the impurity of isolated plasmid DNA by spectrophotometric methods ${ }^{3}$. Liposomal and nanoparticular delivery system are the most suitable delivery system for the unstable biological molecules. For this purpose, biocompatible and biodegradable nanoparticular system have important role for the delivery of biological molecules.

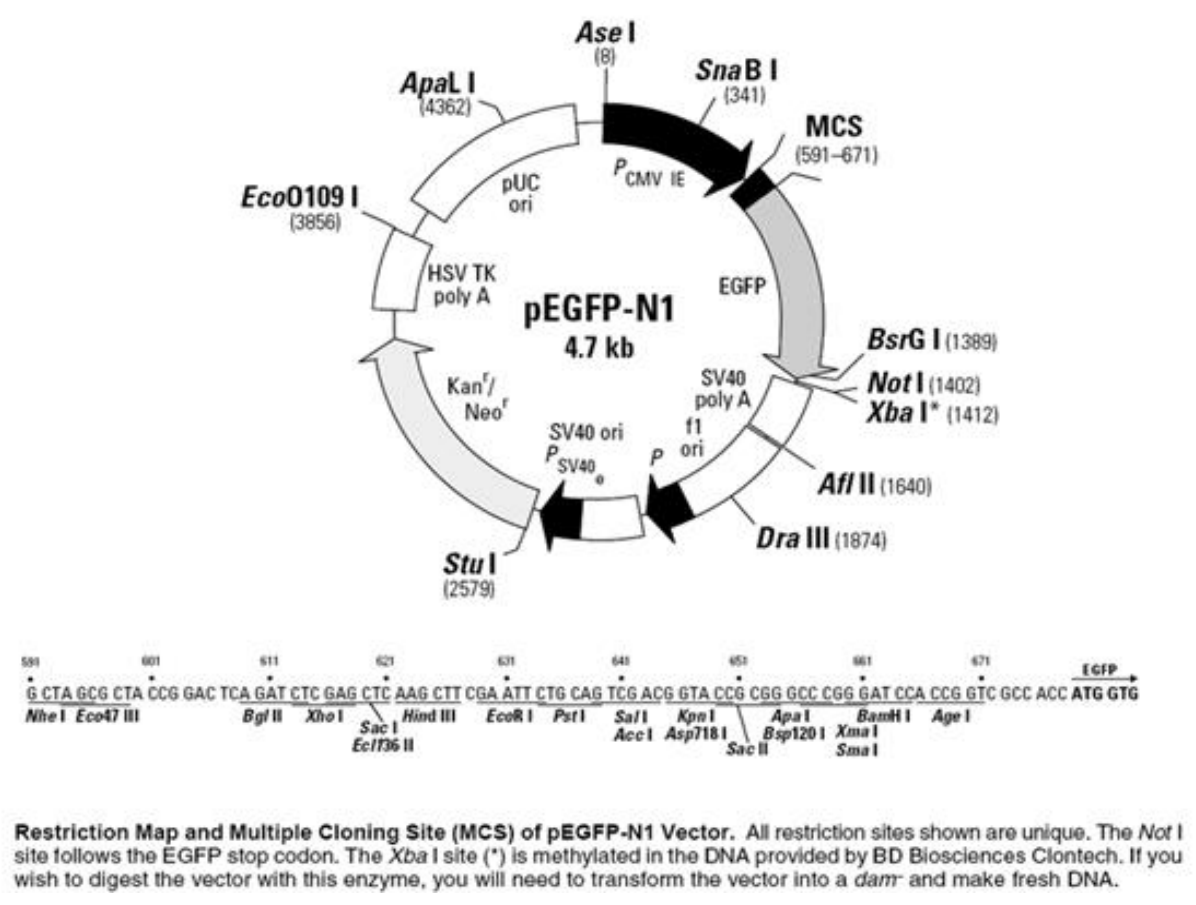

Figure 1: Structure of plasmid peGFP-N1 and gene cassette

\section{MATERIAL AND METHODS}

\section{peGFP-N1 plasmid DNA isolation}

In this study, peGFP-N1 plasmid containing green fluorescent protein as a selection marker was used. In this study, $2 \mathrm{ml}$ of E. Coli bacterial culture was taken into the tube. It was then centrifuged at 10000 rpm for 5 minutes in an ultracentrifuge device. After the supernatant remaining in the upper part was taken to another tube with a micropipette, 250 $\mu 1$ of resuspension solution (RNAase) was added to the sediment at the bottom ${ }^{13}$. It was vortexed until the bottom precipitate got a gel-like consistency. The tube was kept at room temperature for 10 minutes to show RNAase activity. Then, $250 \mu 1$ of lysis buffer (alkaline sodium dodecyl sulfate (SDS) was added to the tube. After this step, the tube was turned upside down and mixed 10-12 times to create a more viscous and clear solution. It was incubated for 2 minutes at room temperature. Then, 
$350 \mu 1$ of neutralization solution was added and the tube was shaken rapidly 10 times by turning it upside down. Then, chromosomal DNA and cell precipitate were centrifuged at $10000 \mathrm{rpm}$ for 5 min. This process was repeated twice. The supernatant was taken to the column, taking care not to allow the precipitate to pass into the supernatant. The amount of supernatant taken to the column is approximately $850 \mu \mathrm{l}$. After this process, the supernatant was centrifuged at 10000 rpm for 1 minute, the supernatant was transferred to the empty tube at the bottom and the column was placed in another tube. $500 \mu 1$ of washing solution was added to the column and centrifuged at 10000 $\mathrm{rpm}$ for $1 \mathrm{~min}$. After the liquid in the lower tube is discarded, the column is placed in a sterile $1.5 \mathrm{ml}$ tube and $75 \mu 1$ of elution buffer is added. After this process, it was left at room temperature for 2 minutes and centrifuged at $10000 \mathrm{rpm}$ for 5 minutes. The column is discarded and kept at -20 ${ }^{\circ} \mathrm{C}$ so that the DNAase enzyme, which may be found in the lower tube, does not show activity.

\section{Creation of the spectral curve equation of plasmid DNA}

An amount of the stock plasmid DNA was taken to generate the spectral curve equation of the peGFP$\mathrm{N} 1$ plasmid. In this study, different concentrations of plasmid DNA dissolved in (Trypsin ethylene diamine tetra acetic acid) TE were used. The absorbance values of each of the plasmid DNA samples at different concentrations were measured at $260 \mathrm{~nm}$ and $280 \mathrm{~nm}$ wavelengths in a UV visible spectrophotometer and the spectral curve equation was calculated according to the results obtained ${ }^{6 \text {, }}$ 14

\section{Quantification of isolated plasmid DNA}

Quantification of the isolated plasmid DNA was performed using UV spectrophotometer. Stock DNA stored at $-20{ }^{\circ} \mathrm{C}$ was taken to room temperature and dissolved. After this process,
Eppendorf tubes were controlled and centrifuged with short spins (5-6 seconds). Then, $990 \mu 1$ of TE buffer was added to the eppendorf tube and $10 \mu \mathrm{l}$ of stock DNA was added to it. The DNA sample was mixed with TE buffer by pipetting. The UV visible spectrophotometer was turned on and made its own checks for the first two minutes. After resetting the device, TE buffer was added to the first of the blue-labeled quartz cuvettes and the transparent surfaces of the cuvette were placed in the back chamber so that they could see the UV light. Then, the sample containing the GFP plasmid was placed in the cuvette and placed in the anterior chamber. Then, absorbance values at $260 \mathrm{~nm}$ and $280 \mathrm{~nm}$ wavelengths and protein and DNA concentrations were measured. Absorbance (A1) $(260 \mathrm{~nm}) /(\mathrm{A} 2)(280 \mathrm{~nm})$ ratio is used to comment on protein and RNA contamination in solution. If this ratio is very close to 1.8 , we can interpret that there is no contamination, if it is higher than 1.8, there is RNA contamination, and if it is less than 1.8 , there is protein contamination. For doublestranded DNA molecules, it is known that 1 optical density (OD) corresponds to $50 \mu \mathrm{g} / \mathrm{ml}$.

Accordingly, the following formula is used to quantify double-stranded DNA:

Equation 1. DNA $(\mu \mathrm{g} / \mathrm{ml})=$ Absorbance $(260 \mathrm{~nm})$ $\times$ dilution rate $\times 50$

\section{RESULTS AND DISCUSSION}

\section{Spectral curve equation result of plasmid DNA}

The spectrophotometric absorbance values read depending on the plasmid DNA concentration showed a linear increase with the increase of the concentration. The significance value of the obtained spectral curve equation is very close to 1 $\left(\mathrm{R}^{2}=0.9989\right)$, which shows that it can be easily used in scientific studies. In Figure 2, the results of the spectral curve equation of plasmid DNA were given.

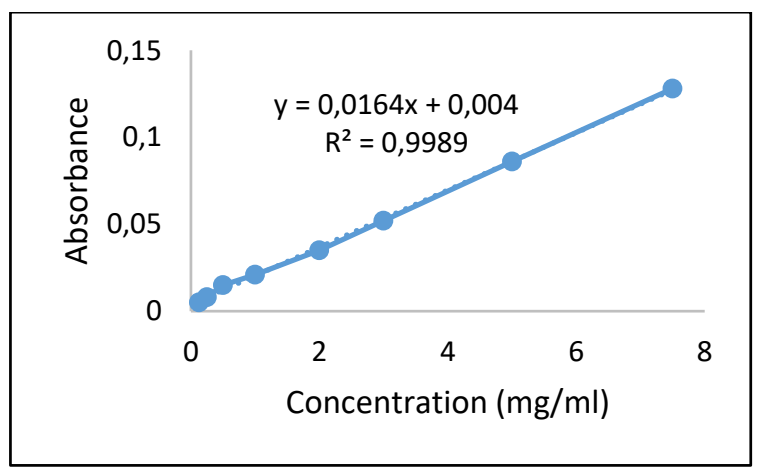

Figure 2: Spectrophotometric analysis results of plasmid DNA. (Predetermined concentrations of plasmid DNA are ranged from $0,125 \mathrm{mg} / \mathrm{ml}$ to $7,5 \mathrm{mg} / \mathrm{ml}$. $x$ and $y$ indicate concentration and absorbance respectively. 
Quantification and impurity evaluation of peGFP-N1 plasmid

The plasmid DNA isolation study was performed triplicate under the same conditions. The results obtained are shown in Table 1. According to the results of the plasmid DNA isolation study, it can be said that isolation number three is the best and most appropriate study in terms of purity. The DNA concentrations obtained in the isolations were calculated according to the Equation 1 given in the method section. The fact that the A1/A2 ratio was very close to 1.8 in these isolation results indicates that no protein and RNA contamination occurred during the study. Therefore, it can be concluded that the efficiency of DNA isolation is quite high. When we evaluated the results of isolation 1, it was observed that the A1/A2 ratio was 1.733, and the protein and DNA concentrations were $2,515 \mathrm{mg} / \mathrm{ml}$ and 2.308 $\mathrm{mg} / \mathrm{ml}$, respectively. The fact that the A1/A2 ratio is lower than 1.8 in this isolation indicates that there is a small amount of protein contamination during the study. According to the results of isolation 2, it was observed that the ratio of A1/A2 was 1.906, and the protein and DNA concentrations were $1.985 \mathrm{mg} / \mathrm{ml}$ and 2.105 $\mathrm{mg} / \mathrm{ml}$, respectively. The A1/A2 ratio in this study is greater than 1.8 , indicating RNA contamination during the study. Such contaminations can be encountered in the working environment due to the enzymes, materials and solvents used, as well as the ambient conditions.

Table 1: Results of plazmid DNA isolations

\begin{tabular}{|l|l|l|l|}
\hline & Isolation I & Isolation II & Isolation III \\
\hline $\mathbf{A 1}(\mathbf{2 6 0} \mathbf{~ n m})$ & 0,052 & 0,061 & 0,059 \\
\hline $\mathbf{A 2}(\mathbf{2 8 0} \mathbf{~ n m})$ & 0.030 & 0,032 & 0,033 \\
\hline $\mathbf{A 1} / \mathbf{A 2}$ & 1,733 & 1,906 & 1,787 \\
\hline DNA concentration & $2,308 \mathrm{mg} / \mathrm{ml}$ & $2,105 \mathrm{mg} / \mathrm{ml}$ & $2,508 \mathrm{mg} / \mathrm{ml}$ \\
\hline Protein concentration & $2,515 \mathrm{mg} / \mathrm{ml}$ & $1,985 \mathrm{mg} / \mathrm{ml}$ & $2,534 \mathrm{mg} / \mathrm{ml}$ \\
\hline
\end{tabular}

\section{CONCLUSION}

The purity of the therapeutically effective plasmid DNA to be used during the studies was determined. A260/280 ratio indicates the purity of DNA. A 260/280 ratio of pure DNA solutions is between 1.8-2. (Chiang et al., 2005). The purity of the plasmid DNA isolated in the study was found in this range.

\section{Acknowledgements}

The authors thank the management of the Sivas Cumhuriyet University, School of Pharmacy, Sivas, Turkey, and Marmara University, Faculty of Pharmacy, Department of Pharmaceutical Biotechnology for providing the necessary facilities and knowledge to conduct this study.

\section{Conflict of Interest}

The authors declare that they have no conflict of interest.

\section{Funding}

No funding sources for research.

\section{Ethical Statement}

This research article has no ethical statement was required.

\section{REFERENCES}

1. Chiang CL, Sung CS, Wu TF. et al. Application of superparamagnetic nanoparticles in purification of plasmid DNA from bacterial cells. J. Chromatogr B Analyt Technol Biomed Life Sci. 2005; 822(1-2): 54-60. doi: 10.1016/j.jchromb.2005.05.017

2. De Toro M, Garcillán-Barcia MP, De La Cruz F. Plasmid diversity and adaptation analyzed by massive sequencing of Escherichia coli plasmids. Microb. Spectr. 2014; 2: 219-235. doi: 10.1128/microbiolspec. PLAS-0031-2014

3. Higuchi Y, Kawakami S, Hashida M. Strategies for in vivo delivery of siRNAs: recent progress. BioDrugs 2010; 24(3):195-205. doi: 10.2165/11534450-000000000-00000.

4. Kav AB, Benhar I, Mizrahi I. A method for purifying high quality and high yield plasmid DNA for metagenomics and deep sequencing 
approaches. J. Microbiol. Methods 2013; 95: 272-279. doi: 10.1016/j.mimet.2013.09.008

5. Kim EJ, Park TG, Oh YK. et al. Assessment of siRNA pharmacokinetics using ELISAbased quantification. J Control Release 2010; 143:80-87. doi:10.1016/j.jconrel.2009.12.004

6. Klindworth A, Pruesse E, Schweer T. et al. Evaluation of general 16S ribosomal RNA gene PCR primers for classical and next-generation sequencing-based diversity studies. Nucleic Acids Res. 2013; 41: e1. doi: 10.1093/nar/gks808.

7. Sentchilo V, Mayer AP, Guy L. et al. Community-wide plasmid gene mobilization and selection. ISME J. 2013; 7: 1173-1186. doi: 10.1038/ismej.2013.13

8. Shan Z, Wu Q, Wang X. et al. Bacteria capture, lysate clearance, and plasmid DNA extraction using $\mathrm{pH}$-sensitive multifunctional magnetic nanoparticles. Anal Biochem. 2010; 398(1): 120-2. doi: 10.1016/j.ab.2009.11.006.

9. Stadler J, Lemmens R, Nyhammar T. Plasmid DNA purification. J Gene Med. 2004; 6 (1): S54-66. doi: 10.1002/jgm.512.
10. Stewart EJ. Growing unculturable bacteria. J. Bacteriol. 2012; 194: 4151-4160. doi: 10.1128/JB.00345-12.

11. Tan SC, Yiap BC. DNA, RNA, and Protein Extraction: The Past and The Present. Journal of Biomedicine and Biotechnology 2009; 1-10. http://dx.doi.org/10.1155/2009/574398

12. Tseng YC, Mozumdar S, Huang L. Lipidbased systemic delivery of siRNA. Adv Drug Deliv Rev. 2009; 61:721-731. doi: 10.1016/j.addr.2009.03.003

13. Warburton PJ, Allan E, Hunter S. et al. Isolation of bacterial extrachromosomal DNA from human dental plaque associated with periodontal disease, using transposon-aided capture (TRACA). FEMS Microbiol. Ecol. 2011; 78: 349-354. doi: 10.1111/j.15746941.2011.01166. x

14. Yeung BZ, Lu Z, Wientjes GM. et al. High Sensitivity RT-qPCR Assay of Nonlabeled siRNA in Small Blood Volume for Pharmacokinetic Studies: Application to Survivin siRNA. AAPS J. 2015; 17(6): 147582. doi: $10.1208 / \mathrm{s} 12248-015-9812$ 